\title{
Mit várunk a szállodáktól? - avagy a legmeghatározóbb fogyasztói szegmens számára értéket jelentő tényezők a szállodákban
}

\author{
Szerzők: Kulcsár Noémi ${ }^{1}$ - Grotte Judit ${ }^{2}$
}

Napjainkban a turisztikai és szállodai szolgáltatások iránti kereslet és legfóképpen az élmények tartalma átalakult, és szegmensenként más-más elvárásokkal és értéket jelentô tényezókkel párosult. Ez a fogyasztói szokásokban végbemenô változás nagy mértékben határozza meg a turisztikai szolgáltatók, ezen belül is a szállodák menedzsment és marketing tevékenységét itthon és külföldön egyaránt. Jelen tanulmány a legmeghatározóbb fogyasztói szegmens, az Y és Z generáció, esetében vizsgálja kérdôives felmérés segítségével a szállodai tartózkodásuk során számukra értéket jelentô tényezóket. A vizsgálat a fogyasztói értéknek a szakirodalomban elterjedt kognitív - affektív értékdimenziós lehatárolása alapján történt. Az elemzés során meghatároztuk a szegmens számára értéket és a szállodai szolgáltatások közül élményt jelentô tényezőket, valamint azonosítottuk utazásuk alatti viselkedésük jellemzőit. Ezt követôen generációs bontást végeztünk, és nem parametrikus varianciaanalizis segítségével megvizsgáltuk az Yés a Z generáció számára értéket jelentố tényezốk közötti különbséget.

Kulcsszavak: szálloda, Y generáció, Z generáció, élmény, érték.

\section{Bevezetés}

Napjaink piaci struktúráját tekintve nem kérdés, hogy a sikeres vállalati múködés és a piacorientáció egyik vezérfonala a feltárt vevői igény kielégítése. Így a vállalat versenyképességét döntô mértékben meghatározza, hogy képes-e vevőinek tartósan értéket teremteni (CHIKÁN - DEMETER 2004). GALLARZA és GILL (2008) tanulmányában szintén hangsúlyozza, hogy a vevőknek nyújtott érték vizsgálata egyrészt a menedzsment számára fontos stratégiai vonatkozásai miatt, másrészt a fogyasztói magatartásvizsgálatok tekintetében releváns és meghatározó. A fogyasztói érték vizsgálatára, mint a hosszú távú üzleti teljesítmény (OH 2000), illetve az ismételt vásárlás (JAYANTI - GHOSH 1996) egyik fó indikátorára, napjainkban az akadémiai világ és a szakmai kutatások is növekvő figyelmet fordítanak.

A menedzsment irodalom elismert fogyasztói érték kutatói, WOODRUFF (1997), HOLBROOK HIRSCHMAN (1982), HOLBROOK (1999), illetve

\footnotetext{
1 egyetemi docens, Budapesti Metropolitan Egyetem, nkulcsar@metropolitan.hu

2 egyetemi docens, Budapesti Metropolitan Egyetem, jgrotte@metropolitan.hu
}

SPARKS és szerzőtársai (2007) is mindannyian hangsúlyozzák, hogy az érték leginkább a fogyasztói élményekben ragadható meg. Az élményérték és a vevő számára jelentkezó érték közötti kapcsolat vizsgálatának egyik jelentôs területe lehet a szállodaipar, hiszen jellegéből adódóan az élménynyújtás kiemelt szektora.

Napjainkban a turizmusban, és azon belül kiemelten a szállodák piacán, a fogyasztói elvárások gyors ütemú változását láthatjuk a vásárlói magatartás átalakulása miatt. Ezek az elvárások pedig nemcsak fogyasztói csoportonként, hanem egy adott szegmens esetében akár egyik évról a másikra is változhatnak. A Horwath HTL turisztikai megatrend kutatásában megállapította, hogy bár nem a legnagyobb fogyasztói szegmens, de biztosan a legmeghatározóbb és legerôsebb fogyasztói csoport jelenleg az Y (Millennials) és a Z (iGen / Click'n go children / Screenagers) generáció tagjai. ${ }^{3}$ E szegmensek szülöttei kiváló technológiai érzékkel és tudással rendelkeznek, kommunikációs, fogyasztói és élményigényük teljesen különbözik az előző generációk igényeitől, ugyanakkor e szegmensek egymáshoz viszonyított vásárlási szokásai és élményelvárásai között is különbségek figyelhetők meg. A szolgáltatóknak már nem csupán az Y generációs igényeknek való megfelelésre kell törekedniük, ha-

$3 \mathrm{http} / / /$ corporate.cms-horwathhtl.com/wp-content/uploads/sites/2/2015/12/Tourism-Mega-Trends4.pdf, Letöltve: 2016. október 10. 
nem versenyképességük növelése érdekében minél hamarabb a Z generáció élményelvárásait is meg kell ismerniük, azokra fel kell készülniük, hiszen e nemzedék fogyasztói szokásai alapjaiban változtatják meg a szolgáltatók eddigi piaci stratégiáját, menedzsment és marketing politikáját.

Jelen tanulmány e két meghatározó piaci szegmens, az Y és a $Z$ generáció szállodai szolgáltatásokkal szembeni elvárásait és a számukra élményt jelentő tényezóket vizsgálja. Kutatási kérdéseinket mindezek értelmében az alábbiak szerint határoztuk meg:

- K1. Mi jellemzi az Y és Z generáció utazási szokásait?

- K2. Milyen elvárásokat támasztanak a szállodákkal szemben, és ezek közül melyek a legfontosabbak?

A tanulmány következó fejezete nemzetközi kitekintésben vizsgálja az említett szegmensek fogyasztói szokásait és a szállodai szakma kihívásait. Ezt követôen ismertetjük kutatásunk módszertanát. A tanulmány eredményeink bemutatásával, következtetéseink levonásával folytatódik, majd az összefoglaló gondolatainkkal zárul.

\section{Szakirodalmi áttekintés}

\subsection{FOGYASZTÓI ELVÁRÁSOK, ÉRTÉKEK ÉS ÉLMÉNYEK}

A fogyasztói magatartás, a fogyasztói igény, elvárás és érték kutatások, valamint ezekkel párhuzamosan a fogyasztói élmény kutatások a „kereslet húzta” piaci átrendeződések és a személyre szabott szolgáltatások iránti igény elterjedése miatt nemcsak a nemzetközi turisztikai piacon, hanem hazánkban is egyre gyakoribbak, hiszen a fogyasztók számára teremtett érték a vállalatok, szolgáltatók versenyképességének feltétele (vö. KULCSÁR 2017). E fogyasztói érték koncepció több megközelítés alapján is vizsgálható: termékközpontú értékesítési szemléletből kiindulva (KOZMA 2009), a Kotler-féle marketing-koncepción (vö. KOTLER 2003) és a közelmúltban elótérbe kerüló $\mathrm{CRM}^{4}$-en keresztül a fogyasztói élmény-menedzsmentig (KOZMA 2009). Ezen újabb értelmezések szerint a fogyasztói érték nagyrészt szubjektív (HOFMEISTER et al. 2003), azaz a fogyasztó személyes véleményét tükrözi arról, hogy a kapott termék és szolgáltatás mennyiben felel meg az elvárásainak. Annak érdekében, hogy ezt a vállalkozások megértsék és beépíthessék piaci stratégiájukba, nagy kihívásokkal kell szembenézniük.

4 Customer Relationship Management = vevőkapcsolat menedzsment
Az értéknek e szubjektív megfogalmazása igen átfogó, amelyet a vevói értékdimenziók (value dimensions) fogalmán keresztül bonthatunk ki (GELEI 2006). Az értékdimenziók elemeire bontják a vevői értéket és azt mutatják meg, hogy a kapott termék-, szolgáltatáscsomagnak melyek azok a fontosabb összetevői, dimenziói, amelyek jelentôs mértékben hozzájárulnak a vevói érték növekedéséhez.

A szálloda szektorban megjelenő fogyasztói értékdimenziók feltárásához releváns megközelítés a multidimenzionalitás vizsgálata. A fogyasztói érték összetevói között:

- egyrészt megjelenhetnek a racionális (kognitív) döntésből adódó és funkcionalitásra összpontosító dimenziók (például az egyes szolgáltatáselemek ára és minósége),

- másrészt a fogyasztó termékkel kapcsolatos megítélésére ható affektív dimenziók (például a hangulat, érzések, kapcsolatok, élmények).

Az élmény értékdimenzió tágabb értelemben is értelmezhetô, előfordulhat, hogy az affektív dimenziók összességét is magában foglalja. De YUAN és WU (2008) szerint akár a teljes fogyasztói értékítélet alapulhat magán a komplex élményen. A hotel szektorban a fogyasztói (vendég) élményelvárások adhatják a fogyasztói érték legnagyobb részét, ezért a különválasztás nehézkes, leginkább a fent említett affektív és kognitív dimenziók mentén végezhetó el.

Jelenleg az Y generáció szülöttei 86 millióan vannak és 200 milliárd dolláros vásárlóerôvel rendelkeznek, amivel ők képezik a legjövedelmezôbb szegmenst a szállodák számára (JUNVI 2015). Annak ellenére, hogy a Z generáció meglehetôsen fiatal, ók befolyásolják a családi költéseket, mely jelenleg több, mint 600 milliárd dollárt jelent. Továbbá ók azok, akik hetente 16,90 dolláros zsebpénzt kapnak, ami 44 milliárd dollárt jelent évente, 2020-ra pedig ők alkotják majd a világ vásárlóinak $40 \%$-át. A Z generáció mint vásárlói csoport évi 3 milliárd dollárral hagyja le az Y generációt (DONOVAN 2017).

Mindezek alapján azt látjuk, hogy bár nem az Y és $Z$ generáció napjaink legnagyobb piaci szegmense, kétségkívül ók rendelkeznek a legmeghatározóbb vásárlóerôvel, ezért fogyasztói szokásaik és a számukra értéket/élményt jelentő tényező́k feltárása kiemelten fontos a turizmusban ugyanúgy, mint a többi szektorban.

\subsection{AZ Y GENERÁCIÓ ELVÁRÁSAI ÉS FOGYASZTÁSI SZOKÁSAI}

Az Y generáció, vagy más néven Millenárisok ezredfordulós generáció-, jellemzően 1980-1994 kö- 
Lektorált tanulmányok

zött jöttek a világra és már beleszülettek a digitális érába.

PÁL és TÖRŐCSIK tanulmányukban (2013) - a generációk bemutatására vonatkozóan - ennél a generációnál arra is felhívják a figyelmet, hogy ő́k a mának élnek, nem terveznek hosszú távra, számukra a legfontosabb, hogy mindig jól érezzék magukat. Nagyon kötődnek barátaikhoz, akikkel a közösségi médián keresztül is tartják a kapcsolatot. Az interneten keresztül könnyen ismerkednek külföldiekkel és gyorsabban fogadják el a kulturális differenciákat (McCRINDLE WOLFINGER 2010). A publikációból az is kiderül, hogy az Y generáció könnyen elfogadja a változást, hiszen ebben nőtt fel. „Számukra a siker, karrier, pénz fogalma elsőrendú fontosságú, mert megtanulták, hogy a fogyasztói társadalomban csak ez visz előre. Már nem „engedelmes munkaerők”, hanem sokszor öntörvényú személyiségek, akiknek a munkahely csak egy a sok közül, amit bármikor lehet változtatni" (TARI 2010:23).

E szegmens számára a legfontosabb a hatékony, gyors és naprakész információáramlás a különböző online felületeken, mint a Facebook, Twitter, Yelp, Tripadvisor stb. Az Y generáció már mindent elektronikusan intéz: a szállodai foglalástól kezdve a bejelentkezésen vagy az éttermi számla rendezésén keresztül a szállodával kapcsolatos problémáik rendezéséig. ERDEINÉ KESMÁRKI-GALLY (2015) szerint a digitális korszakban például egy elektronikus piactér nemcsak a kereslet és kínálat találkozásának helyszíne, hanem egy tudásbázis is.

Az Y generáció utazása előtt elsődlegesen a különbözố online véleményoldalakat tanulmányozza (például Tripadvisor), és bizalmát abba a szállodába helyezi, amelyról a legjobb visszajelzéseket olvassa. YU és SINGH (2002) szerint az elektronikus kereskedelem egyik legnagyobb kihívása a bizalom megteremtése a felek között. BARANYAI és szerzôtársai (2017) úgy vélik, nemzetgazdasági ágazattól függetlenül kijelenthető, hogy a partnerek közötti magas szintú bizalom a gazdasági tranzakciók hatékonysága és eredményessége szempontjából kulcsfontosságú. Kutatásukban bizonyították, hogy a termelők közötti magasabb szintú bizalom statisztikailag is igazolhatóan jobb teljesítményt és a jobb pénzügyi eredményességen keresztül magasabb elégedettséget eredményezett egy termelői szerveződésben (BARANYAI et al. 2017). Ez a szállodaiparban is így múködik, hisz minél elégedettebb a vendég egy adott szállodával és annak szolgáltatásával, annál jobb véleményt fog írni a különféle szállásértékelő oldalakra, amivel növeli a szálloda népszerúségét és egyben bevételét.
Az Y generációs vendégek jellemzóen olyan szállodákat keresnek, amelyek trendi dizájnt, digitális újításokat és személyre szabott szolgáltatásokat nyújtanak, továbbá a helyi változatos programok mellett biztosítják számukra a "wow" hatást. ${ }^{5}$

A vásárlói igényekre történő gyors reagálást segíti eló az új technológiák és trendek alapos ismerete is. Éppen ezért a legnagyobb szállodai márkák elkezdtek összeolvadni a különböző boutique szállodaláncokkal, amire az egyik legjobb példa az IHG (InterContinental Hotels Group PLC) és a Kimpton ${ }^{6}$ egyesülése, melyre akkor került sor, miután rájöttek arra, hogy az Y generáció vásárlói szokásai eltérnek az eddigiektől, hisz nem a standardizált szolgáltatásokat, hanem a személyre szabottakat részesítik elónyben. ${ }^{7}$

Az új innovatív technológiai megoldások egyre több vendéget vonzanak a digitális éra generációjából is. Az egyik ilyen nóvumot már több nemzetközi szállodalánc is alkalmazza, bár egyelőre még csak a húséges, visszatérô vendég programban résztvevó vásárlók körében. Ennek keretében a vendégek már elektronikusan is be tudnak jelentkezni érkezéskor a szállodába, amit megtehetnek mobiltelefonról, vagy akár egy Apple óráról is. Ez a folyamat úgy múködik, hogy amikor a vendégszoba visszaigazolása megtörténik, a vendég azonnal kap egy sms-t, melyben a szálloda tájékoztatja a vendéget a szobaszámról, a bejelentkezés és kijelentkezés idejéről, illetve egyéb fontos információkról. Az érkezés napján, az új technológiai megoldásnak köszönhetően, a vendégnek nem kell személyesen odafáradnia a recepcióhoz, hanem egyszerúen felmegy a szobájába és vagy a telefonját vagy az Apple óráját szobakulcsként tudja alkalmazni (SANGHI 2014). Jelenleg kizárólag az Apple céggel van ilyen szállodai megállapodás.

A Hilton Worldwide világszerte több, mint 3700 szállodájában vezette be a húségprogramban (HHonors) résztvevő vendégek számára a digitális vendégérkezést szobaválasztási funkcióval (HILTON WORLDWIDE 2014). A Starwood szállodalánc már több szállodai márkájánál - mint az Aloft, Element és $\mathrm{W}$ hotelek - bevezette a mobiltelefonos szobakulcs megoldást. A láthatatlan vendégérkezés egyfelól jó a szállodának, hisz ezzel a megoldással csökkenteni tudják a Front Desk túlterheltségét, másfelól jó a vendégeknek, hisz kényelmes, nyugalmas, gyors szolgáltatásban részesülhetnek, amely még a szálloda Tripadvisor pontjainak növekedésében is megnyilvánulhat (KINSELLA 2015).

\footnotetext{
5 http://kamaraonline.hu/cikk/ma-mar-csak-ilyen-szallodabamegy-az-y-generacio, Letöltve: 2017. november 5.

6 https://www.kimptonhotels.com/ihg-faq, Letöltve: 2017. november 5.

7 https://www.daylighted.com/blog/millennials-in-the-hospitality-industry-how-hotels-need-to-adapt/, Letöltve: 2017. november 4.
} 
Bár a turisztikai, szállodai szektor egyik legmarkánsabb szegmense jelenleg az Y generáció, a szakemberek már elkezdték feltérképezni az óket követő Z generáció jellemzőit, szokásait.

\subsection{A Z GENERÁCIÓ FOGYASZTÁSI ÉS KÖLTÉSI SZOKÁSAI}

A Z generáció kifejezést McCRINDLE (2012) az 1995-2010 között született generációra, vagy más néven a digitális bennszülöttekre használja.

A Pécsi Egyetem a Z generáció fogyasztói szokásait vizsgáló kutatásában (PÁL - TÖRŐCSIK 2013) szintén arra a megállapításra jut, hogy a Digitális Generáció még gyorsabban éli az életét, mint az Y generáció, melynek momentumait folyamatosan megosztja a nyilvánossággal.

Fontos számukra: a személyi szabadság, a praktikusság, az elektronikus eszközök ismerete és magas szintú kezelése, valamint a kezdeményezőkészség és a bátorság. Nem félnek a változástól, hisz ebbe a makro környezetbe születtek bele, továbbá nem érdekli ôket a szabályok betartása sem. Nem igazán tudják érzéseiket kifejezni, így a szavak és érzelmek kevésbé jellemzik a generációt. Fogyasztói szempontból a lojalitás nem erôsségük.

A Horwath HTL kutatása ${ }^{8}$ szerint a Z generációra, amely teljesen integrálódott a digitális világba és könnyen alkalmazkodik a változásokhoz, különös figyelmet kell fordítania a turizmus szektornak. A szállodáknak például felül kell vizsgálniuk hosszú távú stratégiáikat, és mérlegelniük kell, hogy az általuk nyújtott szolgáltatások megfelelnek-e e nemzedék szükségleteinek és elvárásainak. Ami eddig hatékonyan múködött a szállodákban, nem biztos, hogy továbbra is hatékony lesz ennek a fogyasztói szegmensnek az esetében. E generáció fogyasztói szokásainak megismerését és a hozzájuk való alkalmazkodást mihamarabb el kell kezdeni. A Z generáció valós idejû́ információkat, rövid, mégis nagyon hatásos üzeneteket vár el, többnyire képekben és videókban, olyan csatornákon keresztül, amelyek lehetôvé teszik számukra az interakciót, az együttes létrehozást (co-creation) és az információk megosztását. Hangulatjelekkel és matricákkal kommunikálnak, amelyek a hagyományos szövegeket helyettesítik.

A turisztikai szolgáltatóknak meg kell tanulniuk a digitális bennszülöttek speciális nyelvét, hogy interakcióba léphessenek és kommunikálhassanak velük. A Z generációnak nyújtott szolgáltatások piacának megteremtése érdekében a vállalatoknak több platformon keresztül kell megismertetniük a történetüket, és bemutatni értékeiket. Továbbá

8 http://corporate.cms-horwathhtl.com/wp-content/uploads/si tes/2/2015/12/Tourism-Mega-Trends4.pdf, Letöltve: 2016. október 10. kiváló márkákat kell létrehozniuk, társadalmilag felelősnek kell lenniük, és ezen fogyasztói csoportot is felnőttként kell kezelniük, tisztelniük kell a véleményüket, hogy létrejöhessen a közösen kialakított szolgáltatás. A szolgáltatások fogyaszthatóságának és személyre szabásának szükségessége esetükben most nagyobb, mint valaha.

TARI (2011) ugyanakkor felhívja a figyelmet arra, hogy ők az első globális nemzedék, ami azt jelenti, hogy - nemzetiségtől függetlenül - ugyanazon ételeket és zenéket szeretik, ugyanabban a kultúrában nónek fel, sőt ugyanazokat a divatmárkákat használják a világ minden részén, hisz mindig, mindenki online van, akár okos telefonon, akár más információs technológiai eszközön.

A Z generáció online költési szokásait térképezte fel ROCHE (2016), aki cikkében leírja, hogy 2020-ra már a Z generáció teszi ki a vásárlók legnagyobb csoportját: az Egyesült Államokban, Európában, Brazíliában, Oroszországban, Indiában és Kínában $40 \%$-ban, a világ többi részén pedig 10\%-ban

A szolgáltatóknak tudomásul kell venniük, hogy ez a generáció merőben más, mint elődjeik, ezért ismerni kell fogyasztói szokásaikat, költési mintájukat. A digitális generáció 4 kulcsfontosságú költési szokásai a következők:

- Vásárlásaik során, nem márkahúek. A Z generáció számára maguk a termékek sokkal fontosabbak, mint a márka. Ezek a vásárlók nagyon gyorsan és könnyen váltanak márkát abban a reményben, hogy magasabb minőséget találnak.

- Evés, alvás, légzés csak digitálisan. A Z generáció állandóan a digitális környezetben él. Éppen ezért a kereskedelemmel szemben is digitális elvárásai vannak.

- Saját kutatást végeznek. A Z generáció kb. 57\%-a végez saját kutatást a vásárlandó termékek körében, mielőtt meghozná vásárlási döntését.

- Szívesebben vásárolnak online (ROCHE 2016).

A Z generáció jövedelmének jóval magasabb részét költi el online, mint az előzó generációk. Minél többen kerülnek ki majd közülük a munkaerópiacra, annál nagyobb lesz online költésük is. A szolgáltatóknak nem csak azzal kell tisztában lenniük, hogy a Z generáció mikor, mit és hol vásárol, hanem azzal is, hogy ezek a vásárlások milyen technológiai eszközökön keresztül történnek.

Az Egyesült Államokban az IBM és a National Retail Federation (NRF) legfrissebb tanulmánya szerint ${ }^{9}$ a $\mathrm{Z}$ generáció vásárlása során személyre szabott szolgáltatást, interaktív élményeket, vala-

9 http://www.bizreport.com/2017/01/98-of-generation-z-shop-instore-but-challenges-ahead-for-re.html, Letöltve: 2017. december 30. 
mint a legújabb digitális megoldásokat (előnyöket) várja el a szolgáltatótól. A felmérésből többek között az is kiderül, hogy a Z generáció mire költ. Nagyon érdekes, hogy a lista élén az ételek és italok állnak 77\%-kal, amit a bútorok (76\%) és háztartási eszközök (73\%) követnek, majd a negyedik helyet az utazások (66\%) foglalják el.

A leggyakrabban használt technológiai eszközök: az okos telefon (75\%), laptop (45\%), számítógép $(30 \%)$, tablet $(10 \%)$, Xbox $(8 \%)$, interaktív, okos TV (3\%), illetve hordható eszközök például óra $(1 \%)^{10}$

A tanulmányból is jól érzékelhetô, hogy a szolgáltatóknak képezniük kell magukat ahhoz, hogy ne veszítsék el a legújabb generációt.

\section{Módszertan}

Tanulmányunk célja az Y (1980-1994) és a Z (19952010) generáció fogyasztói szokásainak és elvárásainak megismerése a szállodai szolgáltatások esetében. Empirikus pilot kutatásunk alapját egy kérdőíves megkérdezés adta, amelynek mintavételi keretéül a Budapesti Metropolitan Egyetem Turizmus-vendéglátás alapszakos és Turizmus-menedzsment mesterszakos nappalis és levelezős hallgatóinak listája szolgált. A kérdőíves vizsgálat az elérhető legjobb módszer az olyan kutató számára, aki a közvetlen megfigyeléshez túlságosan nagyméretú alapsokaság leírásához akar eredeti adatokat gyúiteni. A kérdőíves vizsgálatok nagyszerúen megfelelnek nagyobb alapsokaság attitúdjeinek vagy orientációinak mérésére is. Jellemzôjük viszont az alacsony érvényesség és a magas megbízhatóság, ezért a kérdések kialakítására, megfogalmazására és sorrendjére nagy hangsúlyt fektettünk. Az eredmények jól általánosíthatók, de figyelmet kell fordítani a "túláltalánosítás" elkerülésére, azaz célszerú gondot fordítani a kritikus esetek elemzésére is (BABBIE 2000).

Online felületen készített, retrospektív kérdôíves kutatásunkba azon hallgatók kerülhettek be, akik az elmúlt fél évben legalább egy vendégéjszakát szállodában töltöttek itthon vagy külföldön. A kitöltött kérdőívek száma 406 db, melyek közül az adattisztítás után kutatásunkban felhasználható volt $332 \mathrm{db}(\mathrm{N})$. Mintánkba csak a teljesen és korrekt módon kitöltött kérdőívek kerülhettek be, azzal a további korlátozással, hogy a kérdéses szállodai tartózkodás az elmúlt fél éven belül történt. Generációs megoszlást tekintve mintánk közel kiegyensúlyozott, hiszen a válaszadók 45\%-a, 149 fó az Y generáció, míg 55\%-a, 183 fő a Z generáció tagjai közül került ki.

10 https://nrf.com/resources/retail-library/uniquely-gen-z, Letöltve 2017. december 30 .
A kérdőív szúrôkérdéssel indult, majd az utazás alapvetố jellemzőire vonatkozó kérdések után zárt típusú Likert-skálán mért állítások következtek. A szállodai elvárások és élmények mérésére vonatkozó állítások kialakításakor a TCI \& HOTREC RESEARCH (2017) átfogó nemzetközi vizsgálatát vettük alapul, majd ahol szükséges volt, a magyar turisztikai és társadalmi trendekhez igazítottuk. A kérdốiv demográfiai kérdésekkel zárult. A kérdốves felmérés elôtt az érvényesség növelése érdekében teszt kérdőívezést végeztünk, melynek következtében néhány kérdésfeltevést és válaszalternatívát módosítottunk. A felmérésre 2017 novemberében és decemberében került sor.

\section{Eredmények}

Empirikus kutatási eredményeink feldolgozása során leíró, összehasonlító, valamint többváltozós statisztikai elemzéseket végeztünk annak érdekében, hogy kutatási kérdéseinkre választ kapjunk.

\subsection{UTAZÁSI SZOKÁSOK}

A 332 főt számláló mintában a férfiak és nók aránya $18 \%$ és $82 \%$. Kormegoszlást tekintve mintánk 45\%-át az Y, míg 55\%-át a Z generáció tagjai adták.

Kitöltóink utazási céljai jól igazodnak a magyar lakosok által a központi statisztikák gyújtése során megjelölt utazási célokhoz.

A megkérdezettek többsége $(54,8 \%)$ üdülési és pihenési célból utazott az elmúlt fél évben, a második leggyakoribb utazási cél a városlátogatás volt (19,3\%), melynek oka valószínúsíthetóen a fapados repülójáratok adta európai nagyvárosok kedvezményes és gyors elérési lehetôsége, valamint az egyetemisták kulturális turisztikai szolgáltatások iránti megnövekedett fogyasztási igénye. Harmadik leggyakoribb utazási cél a konferencia részvétel, illetve üzleti tárgyalás $(9,3 \%)$ volt, amely az Y szegmens utazásait jellemezte inkább.

A minta szállodában töltött idejét vizsgálva az egy hétvégés, azaz 2 éjszakás tartózkodások gyakorisága a legnagyobb (35\%), ezt követően a $4-7$ éjszakás tartózkodások (27\%) kedveltek, míg a tradicionális hosszabb, akár kéthetes utazások aránya csekély (5\%).

Az utazások rövid idótartamával azonban fordított arányosságot mutat azok gyakorisága, hiszen a kitöltók 60\%-a évente 3-nál több alkalommal is utazik, így utazási szokásaikra nem csupán az éves 1-2 „fố utazáson" való részvétel jellemző, hanem ezek mellett több, rövidebb látogatást is szerveznek különböző desztinációkba.

Felmérésünkben vizsgáltuk a kitöltôk lojalitását is az adott szállodához. Az ismételt visszatérés a 
A vendégek utazás alatti viselkedésének jellemzői

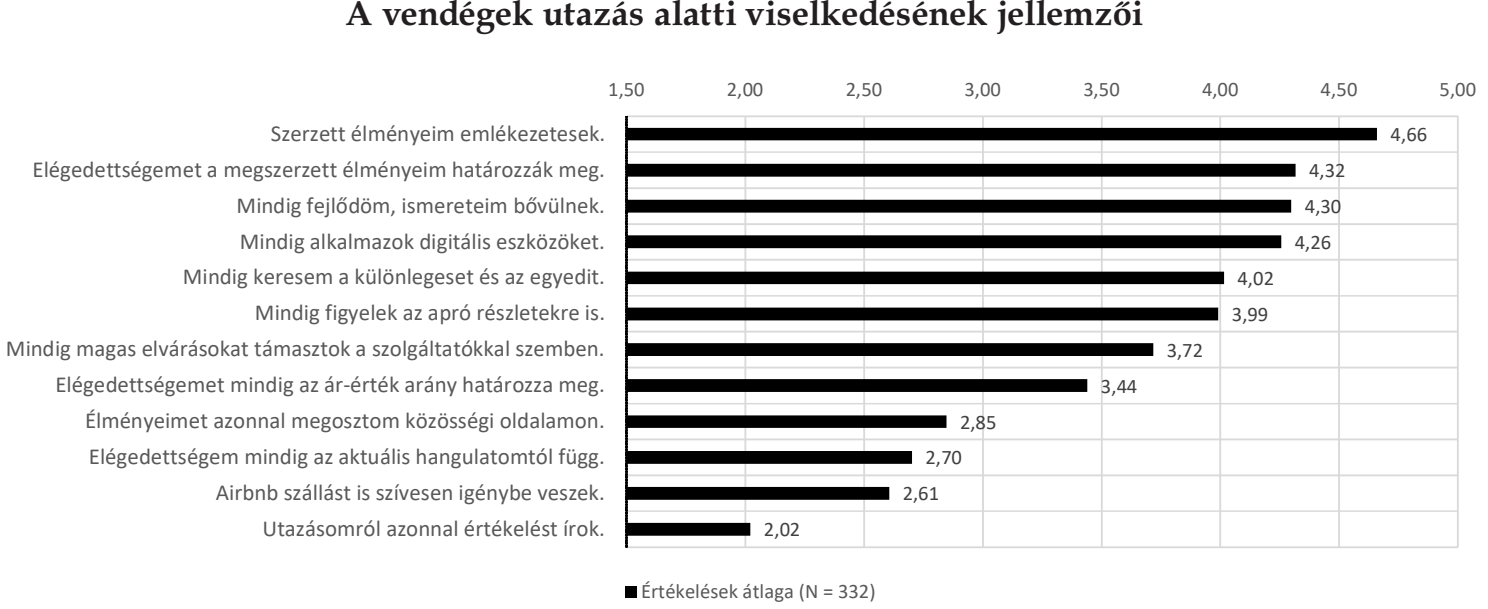

Forrás: saját szerkesztés

megkérdezettekre nem volt jellemző, 78\%-uk nem lojális a szállodákhoz. A választott szálloda kategóriáját tekintve jellemzően 4 csillagos szállodákat választanak szálláshelyként (52\%), de kedveltek a 3 csillagos szállodák is (36\%).

Ez az eredmény összefüggésben áll azzal a ténnyel, hogy nemcsak az Y, hanem a Z generáció tagjai is már rendszeres jövedelemmel rendelkeznek $(70 \%)$, hallgatóink tanulmányaik mellett dolgoznak, így képesek megfizetni a magasabb kategóriájú szállodákat. Kutatásunkból az is kiderült, hogy 1 és 2 csillagos szállodákban, panziókban, hostelekben csak nagyon kevesen szállnak meg, arányuk elenyészố, 1-2 százalék csupán. Az együtt utazók körét tekintve jellem- zóen párjukkal (40\%) és családjukkal (37\%) utaznak.

Kutatásunk során vizsgáltuk, hogy az alanyainkra mennyire igazak bizonyos viselkedésjellemző́k az utazásaik alatt (1=egyáltalán nem igaz, $5=$ teljes mértékben igaz). Összességében igaz e generáció tagjaira, hogy utazásaik alkalmával leginkább a különleges, egyedi programokat és szolgáltatásokat keresik, elégedettségüket a megszerzett élményeik befolyásolják. Élményeik összekapcsolhatók a digitális eszközhasználat lehetôségével, hiszen e lehetőségeket folyamatosan keresik. Az élményeiket általában közösségi oldalaikon is megosztják, ellenben nem jellemzi óket, hogy az utazásaikat online felületen azonnal értékelnék (1. ábra).

\section{Vendégelvárások a szállodákban}

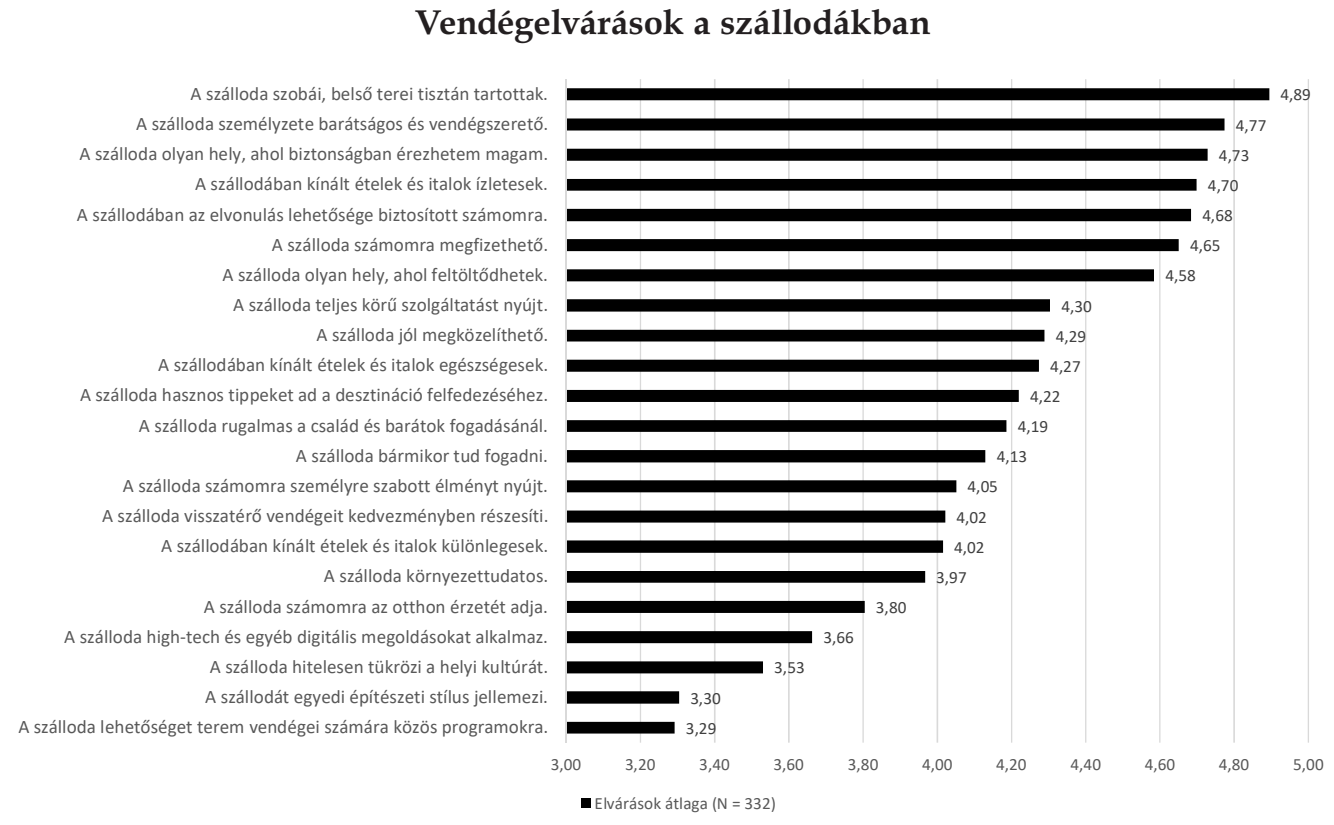

Forrás: saját szerkesztés 
Lektorált tanulmányok

A fenti ábrából látható, hogy napjaink fogyasztói kritikus utazók, akik magas elvárásokat támasztanak. Számukra fontos, hogy az utazás élménydús legyen, a megfelelő áron. Jellemzően úgy érzik, utazásaik alatt fejlődnek, ismereteik bóvülnek. Bátran alkalmaznak digitális eszközöket utazásaik során.

\subsection{FOGYASZTÓI ÉRTÉKET JELENTŐ TÉNYEZŐK, LEGFONTOSABB SZÁLLODAI ELVÁRÁSOK}

A 2. ábráról jól leolvasható, mely tényezők jelentenek értéket (1=egyáltalán nem fontos, $5=$ nagyon fontos) a vizsgált szegmens számára, illetve az is, hogy az egyes tényezók között melyek a legfontosabbak.

A szegmens szállodákkal szemben támasztott legmagasabb (4,5 érték feletti) elvárása a szobák tisztaságával kapcsolatos $(4,89)$, azaz első helyen egy kognitív, minőséghez kötött értékdimenziót jelöltek meg, amit a barátságos és vendégszeretó személyzet $(4,77)$, illetve a biztonság $(4,73)$ követnek. Szintén kiemelkedő fontossággal bír számukra az ízletes ételek, italok kínálata $(4,70)$, az elvonulási lehetőség $(4,68)$, a megfizethetőség $(4,65)$, valamint a rekreációs lehetôség $(4,58)$.

Adatainkat normalitásvizsgálatnak vetettük alá, melynek eredményeként kiderült számunkra, hogy azok nem normál eloszlásúak. Az ANOVA varianciaanalízis vizsgálatot így robusztussága ellenére sem tartottuk megfelelőnek adataink elemzésére. Helyette a Mann-Whitney U-teszttel nem parametrikus varianciaelemzést készítettünk a generációk közötti fogyasztásbeli különbségek azonosítása érdekében. Az értéket jelentő tényezők rangsorában szignifikáns különbség (10\%-os szignifikanciaszinten vizsgálva) az alábbi tényezók esetében volt megfigyelhetô az $\mathrm{Y}$ és a $\mathrm{Z}$ generáció tagjai között (1. táblázat).

Y és Z generáció szállodai elvárásai közötti szignifikáns különbség

\begin{tabular}{|c|c|c|c|c|}
\hline \multicolumn{5}{|c|}{ Mann-Whitney Test } \\
\hline \multicolumn{5}{|c|}{ Rangszámok } \\
\hline \multicolumn{2}{|l|}{ Generáció } & $N$ & Rangátlag & Rangösszeg \\
\hline \multirow{3}{*}{ Egyediség } & $Y$ & 149 & 155,64 & 23191,00 \\
\hline & $Z$ & 183 & 175,34 & 32087,00 \\
\hline & Összesen & 332 & & \\
\hline \multirow{3}{*}{ Közösségi élmény } & $Y$ & 149 & 156,26 & 23282,50 \\
\hline & Z & 183 & 174,84 & 31995,50 \\
\hline & Összesen & 332 & & \\
\hline \multirow{3}{*}{ Személyre szabott élmény } & $Y$ & 149 & 155,33 & 23143,50 \\
\hline & Z & 183 & 175,60 & 32134,50 \\
\hline & Összesen & 332 & & \\
\hline \multirow{3}{*}{ Összesen } & $Y$ & 149 & 173,89 & 25910,00 \\
\hline & $Z$ & 183 & 160,48 & 29368,00 \\
\hline & Összesen & 332 & & \\
\hline \multirow{3}{*}{ Biztonság } & $Y$ & 149 & 174,89 & 26059,00 \\
\hline & Z & 183 & 159,67 & 29219,00 \\
\hline & Összesen & 332 & & \\
\hline \multirow{3}{*}{ Ízletes ételek és italok } & $Y$ & 149 & 173,63 & 25871,00 \\
\hline & $Z$ & 183 & 160,69 & 29407,00 \\
\hline & Összesen & 332 & & \\
\hline \multirow{3}{*}{ Környezettudatosság } & Y & 149 & 176,79 & 26341,50 \\
\hline & Z & 183 & 158,12 & 28936,50 \\
\hline & Összesen & 332 & & \\
\hline
\end{tabular}




\begin{tabular}{|c|c|c|c|c|c|c|c|}
\hline & Egyediség & $\begin{array}{c}\text { Közösségi } \\
\text { élmény }\end{array}$ & $\begin{array}{c}\text { Személyre } \\
\text { szabott } \\
\text { élmény }\end{array}$ & Személyzet & Biztonság & $\begin{array}{c}\text { Ízletes ételek } \\
\text { és italok }\end{array}$ & $\begin{array}{c}\text { Környezet- } \\
\text { tudatosság }\end{array}$ \\
\hline $\begin{array}{c}\text { Mann- } \\
\text { Whitney U }\end{array}$ & 12016,000 & 12107,500 & 11968,500 & 12532,000 & 12383,000 & 12571,000 & 12100,500 \\
\hline Wilcoxon W & 23191,000 & 23282,500 & 23143,500 & 29368,000 & 29219,000 & 29407,000 & 28936,500 \\
\hline Z & $-1,925$ & $-1,801$ & $-2,028$ & $-1,882$ & $-2,024$ & $-1,625$ & $-1,857$ \\
\hline $\begin{array}{c}\text { Asymp. Sig. } \\
\text { (kétoldali) }\end{array}$ & 0,05 & 0,07 & 0,04 & 0,06 & 0,04 & 0,10 & 0,06 \\
\hline a. Csoportositó változó: Generáció & \multicolumn{7}{|c|}{} \\
\hline
\end{tabular}

Forrás: saját szerkesztés

Az Y generáció tagjai számára szignifikánsan nagyobb értékkel bír, ha

- a szálloda biztonságérzetet nyújt,

- környezettudatos,

- barátságos és vendégszerető környezetben van,

- ízletes ételek és italok fogyasztására ad lehetôséget.

Ezzel szemben a Z generációs válaszadók számára lényegesen fontosabb

- az egyedi építészeti stílus és formatervezés,

- a személyre szabott élmény,

- a közösségi élményszerzés lehetősége.

Kutatásunk arra is kiterjedt, hogy megvizsgáljuk, mekkora élményt jelent kitöltőink számára a szállodák által nyújtott szolgáltatások köre (3. ábra). Az értékelést az alanyok 1-tôl 5-ig terjedő skálán végezhették el, ahol az 1 „,az egyáltalán nem jelent élményt számomra”, az 5 pedig „,az igazi élményt jelent számomra” válaszopciót jelölte.

Az ábrából jól látható, hogy a legmagasabb élményértéket a szálloda gasztronómiai szolgáltatásai jelentik, majd ezt követik a wellness $\mathcal{E}$ beauty szolgáltatások, melyek ugyanolyan élménydúsak a megkérdezettek számára, mint a szálloda hangulata, belső tereinek dizájnja. A gyógyászati szolgáltatások és fitnesz szolgáltatások iránt közömbösek, azonban míg előbbi az életkori sajátosságok miatt érthetô, az utóbbi iránti közömbösség meglepó eredmény a szerző́k számára.

Az eredmények kapcsán fontos megjegyezni, hogy az általunk alkalmazott próba eredményei arra vonatkoznak, hogy a vizsgált mintában látható különbségek szignifikánsnak tekinthetôk-e a populáció egészében is. Azonban mintánk nem reprezentatív, így az eredmények általánosíthatósága a nem-paraméteres varianciaanalízis által feltárt szignifikáns különbségek alapján is csak korlátozott.

\section{Szállodai szolgáltatások élményértéke}

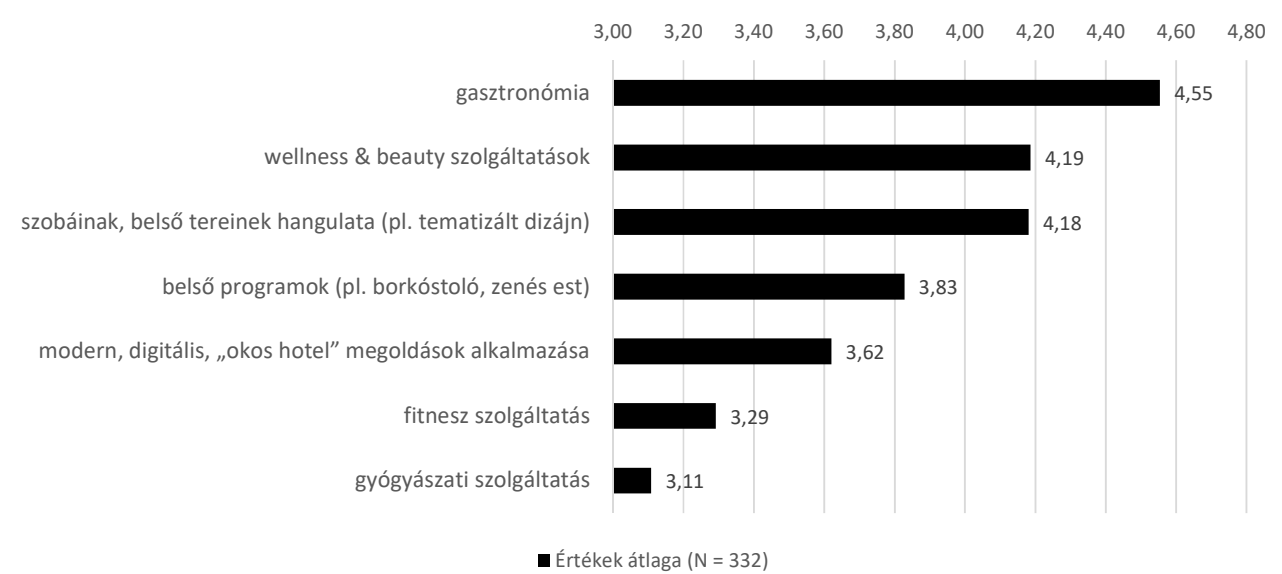

Forrás: saját szerkesztés 


\section{Következtetések és javaslatok}

Pilot kutatásunk során célunk volt feltárni a legmeghatározóbb fogyasztói szegmens utazási szokásait, valamint választ kerestünk azokra a kérdésekre is, mi jelent számukra értéket szállodai tartózkodásuk során, milyen elvárásokat támasztanak a szállodákkal szemben, valamint hogy a szállodák által nyújtott szolgáltatások élményt jelentenek-e számukra.

Eredményeink a tekintetben igazodtak a már tényként kezelt nemzetközi trendekhez, miszerint napjaink turistái éves szinten többször utaznak, e magatartással több élményt is keresve, de utazásik hossza lerövidül. Turistáink egyre kevésbé lojálisak. Láthattuk, hogy az Y és Z generáció tagjai sem azok, új élményékre vágynak, keresik az egyedit, a különlegeset utazásaik során, valamint a személyre szabott élményeket, melyeket digitális eszközök segítségével meg is osztanak közösségi oldalaikon. Láthattuk, hogy kedvelik a hotelek „okos megoldásait", azaz a szolgáltatások digitalizációját, ugyanakkor ez számukra nem élményként, sokkal inkább elvárásként jelenik meg.

Az általunk vizsgált magyar szegmens jellemzői abban a tekintetben viszont eltérést mutatnak a nemzetközi kutatások megállapításaihoz képest, hogy a szállodákkal szemben támasztott legfontosabb elvárásuk a kognitív értékek megléte. Pilot kutatásunkban ez a szobák tisztaságára vonatkozó minőségi tényezőt jelentette, melyet követően a fontossági rangsorban már affektív értékdimenziók jelennek meg, úgy mint a vendégszeretet, relaxáció, gasztronómiai élmények. A szegmens számára kiemelten fontosnak vélt ár dimenzió csupán mindezek után következik az elvárások rangsorában.

A szegmens növekvő vásárlóerejét bizonyítja, hogy a mostani fiatal generáció felsőfokú tanulmányai mellett dolgozik is, teljes értékú jövedelemmel rendelkezik, melyet szívesen költ utazásra, szállodaválasztásai során pedig szívesen választja a magasabb áron elérhetô, akár 4 csillagos szállodákat is.

Kutatásunk eredményei alapján levonható az a következtetés, hogy az Y és Z generáció szállodai elvárásai tekintetében nem jellemzô markáns különbség. Ez adódhat a kutatási korlátból, miszerint az Y és $\mathrm{Z}$ generáció tagjai között esetleg csupán néhány év korkülönbség jelenik meg, amely nem jelent meghatározó különbséget fogyasztási szokásaikban. Ugyanakkor nem hagyható figyelmen kívül az a piaci gyakorlat, miszerint egy bizonyos szegmens fogyasztói szokásai jelentősen változhatnak akár egyik évról a másikra is. Kutatásunkban csupán néhány tényezô esetében tudtunk lényeges különbségeket azonosítani a szegmensek között. E szignifikáns eredményeket adó tényezők (egyediség, különleges dizájn, személyre szabott élmény stb.) azonban jól hasznosíthatóak lehetnek a lifestyle és boutique szállodák kínálatfejlesztése során, hiszen a vizsgált szegmens fogyasztói elvárásainak - eredményeink alapján - leginkább ők képesek megfelelni. És mivel napjaikban nagyobb gazdasági potenciál van ebben a szegmensben, mint az előzố generációk ifjú korában, másképp is kell kezelni őket. Értékrendjük, igényeik és kommunikációs nyelvük megismerése, illetve az azokra adott hatékony szolgáltatói válaszok a szállodák jövőbeni versenyképességét határozzák meg.

\section{6. Összefoglalás}

Napjaink piaci struktúráját tekintve nem kérdés, hogy a sikeres vállalati múködés és a piacorientáció egyik vezérfonala a feltárt vevói igény kielégítése. A turizmusban és azon belül kiemelten a szállodák piacán is a fogyasztói elvárások gyors ütemú változását láthatjuk a vásárlói magatartás átalakulása miatt.

A vizsgált szegmensek szülöttei kiváló technológiai érzékkel és tudással rendelkeznek, kommunikációs, fogyasztói és élményigényük teljesen különbözik az előző generációk igényeitől, ugyanakkor e szegmensek egymáshoz viszonyított vásárlási szokásai és élményelvárásai között is különbségek figyelhetók meg. Tanulmányunkban az Y és a Z generáció fogyasztói szokásait és elvárásait ismertük meg a szállodai szolgáltatások esetében. Empirikus kutatásunk alapját egy kérdôíves megkérdezés adta, melynek mintavételi keretéül a Budapesti Metropolitan Egyetem Turizmus-vendéglátás alapszakos és Turizmus-menedzsment mesterszakos nappalis és levelezôs hallgatóinak listája szolgált. Online felületen készített, retrospektív kérdőíves kutatásunkba azon hallgatók kerülhettek be, akik az elmúlt fél évben legalább egy vendégéjszakát szállodában töltöttek el itthon vagy külföldön

Empirikus kutatási eredményeink feldolgozása során leíró, összehasonlító statisztikai elemzéseket végeztünk annak érdekében, hogy kutatási kérdéseinkre választ kapjunk, ily módon pedig az adott mintán párhuzamot vonhassunk a szegmens utazási szokásai és szállodai elvárásai, valamint a nemzetközi kutatások megállapításai között, illetve pontosabb képet kapjunk a generációk közötti fogyasztói elvárások különbségéról.

Eredményeink a tekintetben igazodtak a már tényként kezelt nemzetközi trendekhez, miszerint napjaink turistái éves szinten többször utaznak, e magatartással több élményt is keresve, de utazása- 
ik hossza lerövidül. Turistáink egyre kevésbé lojálisak. Láthattuk, hogy az Y és $Z$ generáció tagjai sem azok, új élményékre vágynak, keresik az egyedit, a különlegeset utazásaik során, valamint a személyre szabott élményeket, melyeket digitális eszközök segítségével meg is osztanak közösségi oldalaikon. Láthattuk, hogy kedvelik a hotelek „okos megoldásait", azaz a szolgáltatások digitalizációját, ugyanakkor ez számukra nem élményként, sokkal inkább elvárásként jelenik meg. A magyar minta jellemzői abban a tekintetben viszont eltérést mutatnak a nemzetközi kutatások megállapításaihoz képest, hogy a szállodákkal szemben támasztott legfontosabb elvárásuk a kognitív értékek megléte. Kutatásunkban ez a szobák tisztaságára vonatkozó minőségi tényezőt jelentette, melyet követően a fontossági rangsorban már affektív értékdimenziók jelennek meg, úgy mint a vendégszeretet, relaxáció, gasztronómiai élmények.

A szegmensek között markáns különbségek csak elenyészó esetben voltak megfigyelhetők. Talán ez lehet az oka annak is, hogy még nem láttunk külön $Y$ vagy $Z$ szegmens számára specializálódott és tematizált szállodákat. Kutatásunk rávilágított arra, hogy a vizsgált szegmens kereslete egyediségük, tematizáltságuk és személyre szabott élményígéretük miatt leginkább a független szállodák, közülük is a lifestyle, design, illetve témahotelek iránt növekedhet meg. Ez a növekvő vásárlóerő pedig már most arra kell, hogy késztesse a szakmát, hogy mihamarabb megismerje e szegmensek szokásait, a számukra értéket jelentő tényezőket, és ezek mentén alakítsa át szolgáltatáskínálatát, amelyet egy célzott, tömör, de annál figyelemfelkeltőbb módon, digitális eszközökön kommunikál a célcsoport felé. Ez a folyamat egy komplex piaci átrendeződést igényel, hisz eszközhasználati, stílus- és nyelvhasználati változtatásokat is indukál, de kétségkívül a versenyképesség alapját képezi, így a vállalati stratégiában való megjelenésük kritikus.

\section{Felhasznált irodalom}

BABBIE, E. (2000): A társadalomtudományi kutatás gyakorlata. Balassi Kiadó, Budapest.

BARANYAI, ZS. - KOVÁCS, Z. - PAPP-VÁRY, Á. (2017): The effect of trust on the performance and statisfaction of co-operative members at the „Paprikakertész" producer organisation. Annals of the Polish Association of Agricultural and Agribusiness Economists. 19(2). pp. 21-26.

CHIKÁN A. - DEMETER K. (2004): Ertékteremtó folyamatok menedzsmentje. Aula Kiadó, Budapest.

ERDEINÉ KÉSMÁRKI-GALLY, SZ. (2015): Application of a modern marketplace in the
European agribusiness. Agroeconomia Croatica. 5(1). pp. 41-50.

GALLARZA, M. G. - GILL, I. (2008): The concept of value and its dimensions: a tool for analysing tourism experiences. Tourism review. 63(3). pp. 4-20.

GELEI A. (2006): Beszállitó-típusok és azok alapvetô kompetenciái a hazai autóipari ellátási láncban. Doktori (PhD) értekezés. Budapesti Corvinus Egyetem, Gazdálkodástani Doktori Iskola, Budapest.

HOFMEISTER T. Á. - SIMON J. - SAJTOS L. (2003): Fogyasztói elégedettség. Alinea Kiadó, Budapest.

HOLBROOK, M. B. - HIRSCHMAN, E. C. (1982): The experiential aspects of consumption: Consumer fantasy, feelings and fun. Journal of Consumer Research. 9(2). pp. 132-140.

HOLBROOK, M. B. (ed) (1999): Consumer Value: A Framework for Analysis and Research. Routledge, London, New York.

JAYANTI, R. K. - GHOSH, A. K. (1996): Service value determination: an integrative perspective. Journal of Hospitality and Leisure marketing. 3(4). pp. 5-25.

KOTLER, P. (2003): Marketing Management. New Jersey, USA: Pearson Prentice Hall.

KOZMA M. (2009): Értékteremtés Public-Private Partnership keretében - különös tekintettel a vállalkozó szempontjaira. Doktori (PhD) értekezés. Budapesti Corvinus Egyetem, Gazdálkodástani Doktori Iskola, Budapest.

KULCSÁR, N. (2017): Analyzing the consumer value dimensions of rural tourism. Saarbrücken: LAMBERT Academic Publishing.

OH, H. (2000): Diners' perceptions of quality, value and satisfaction. Cornell Hotel and Restaurant Administration Quarterly. 41(3). pp. 58-66.

PÁL E. - TÖRŐCSIK M. (2013): A Z generációról. TÁMOP-4.2.3-12/1/KONV-2012-0016, Tudománykommunikáció a Z generációnak. Pécsi Tudományegyetem, Pécs.

SPARKS, B. - BUTCHER, K. - PAN, G. (2007): Understanding Customer-Derived Value in the Timeshare Industry. Cornell Hotel and Restaurant Administration Quarterly. 48(1). pp. 28-45.

TARI A. (2010): Y generáció: Klinikai pszichológiai jelenségek és társadalomlélektani összefüggések az információs korban. Jaffa Kiadó, Budapest.

TARI A. (2011): Z generáció: klinikai pszichológiai jelenségek és társadalomlélektani szempontok az információs korban. Budapest: Tericum.

WOODRUFF, R. B. (1997): Customer Value: The Next Source for Competitive Advantage. Journal of the Academy of Marketing Science. 25(2). pp. 139-153. 
Lektorált tanulmányok

YU, B. - SINGH, M. P. (2002): Distributed Reputation Management for Electronic Commerce. Computational Intelligence. 18(4). pp. 535-549.

YUAN, Y-H. E. - WU, C. K. (2008): Relationships Among Experiential Marketing, Experiential Value, and Customer Satisfaction. Journal of Hospitality \& Tourism Research. 32(3). pp. 387410.

\section{Internetes források}

DONOVAN, L. (2017): Purchasing power of generation Z. https://www.business2community.com/ consumer-marketing/purchasing-powergeneration-z-01926562, Letöltve: 2018. április 22.

HILTON WORLDWIDE (2014): Truly Opens Doors: Company to Roll Out Mobile Room Keys in 2015 at Hundreds of U.S. Hotels Across Four Brands. http:// www.hiltonworldwideglobalmediacenter.com/ index.cfm/newsroom/detail/27701, Letöltve: 2015. március 21.

JUNVI, O. (2015): How to get Millennials to join your Hotel Loyalty Program. http://hospitality.cvent. $\mathrm{com} / \mathrm{blog} /$ junvi-ola/how-to-get-millennials-tojoin-your-hotel-loyalty-program, Letöltve: 2016. február 15.

KINSELLA, T. (2015): The Hotel Room Key Goes Mobile...What's the Big Deal? https://www. linkedin.com/pulse/hotel-room-key-goesmobilewhats-big-deal-tim-kinsella, Letöltve: 2015. április 12.

McCRINDLE, M. - WOLFINGER, E. (2010): Az $X Y Z$ ábécéje. A nemzedékek meghatározása. ht tp:// korunk.org/letoltlapok/Z_ RKorunk2010november.pdf, Letöltve: 2018. április 20.

McCRINDLE, M. (2012): Generations Defined.http:// mccrindle.com.au/resources/GenerationsDefined-Sociologically.pdf, Letöltve: 2018. április 18 .

ROCHE, M. (2016): Know Your Consumer: 4 Online Spending Habits of Generation Z. http://payments.cardinalcommerce.com/ spending-habits-of-genz, Letöltve: 2017. november 19.

SANGHI, M. (2014): 6 Hotel Hospitality Industry New and Current Trends You Should Know About. http://www.hotelogix.com/blog/2014/02/06/6hotel-industry-trends-you-should-knowabout/\#sthash.6CmoCPKj.dpufhttp://www. hotelogix.com/blog/2014/02/06/6-hotelindustry-trends-you-should-know-about/, Letöltve: 2015. május 25.

TCI \& HOTREC RESEARCH: http://www.hotrec. $\mathrm{eu} /$ newsroom/press-releases-1714/pressrelease-study-hotrec-tci-research-mappinghotel-and-restaurant-future-experience---20june-2017.aspx, Letöltve: 2017. december 2. 